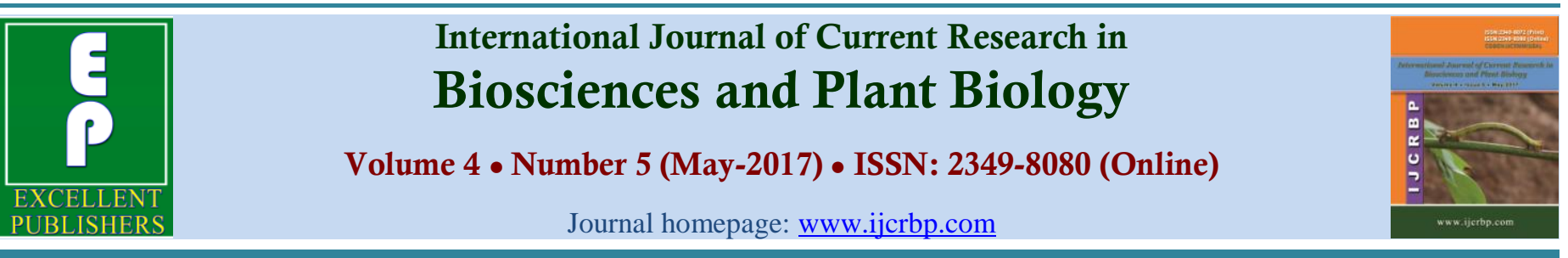

\title{
Postharvest Diseases and Effect of Hot Water Treatments on White Fleshed Dragon Fruit [Hylocereus undatus (Haw.) Britton \& Rose]
}

\author{
Nguyen Khanh Ngoc $^{1}$, Nguyen van Phong ${ }^{1}$, Nguyen Thanh Tung ${ }^{1}$, Nguyen van Hoa ${ }^{1}$, A.B.Woolf ${ }^{2}$ \\ and R.A. Fullerton ${ }^{2}$ \\ ${ }^{I}$ Southern Horticultural Research Institute (SOFRI), My Tho, Tien Giang, Vietnam \\ ${ }^{2}$ New Zealand Institute of Plant and Food Research Limited, Private Mail Bag 92169, Auckland Mail Centre, New Zealand \\ *Corresponding author.
}

\begin{abstract}
Postharvest rots are a significant limitation to the storage life of white fleshed dragon fruit, this paper aimed to identify the main pathogens associated with postharvest diseases in the Mekong delta region, to identify the origins of infections, and to investigate the use of heat treatments for postharvest rot control. Dragon fruit were stored at $0^{\circ} \mathrm{C}, 5^{\circ} \mathrm{C}$ and $10^{\circ} \mathrm{C}$ for 26 days followed by 3 days shelf life at $20^{\circ} \mathrm{C}$. Other fruit were held at $20^{\circ} \mathrm{C}$ for 7 days as a non-stored control. The main fungi associated with postharvest rots were Alternaria alternata, Bipolaris cactivora, Colletotrichum truncatum, Fusarium dimerum, Fusarium equiseti and Rhizopus stolonifer. Skin pieces plated out from freshly harvested surface sterilised fruit yielded $C$. truncatum, $F$. dimerum, $F$. equiseti, A. alternata, and $B$. cactivora. Surface swabs from fruit in the field yielded A. alternata and Fusarium sp. The study showed that, except for those caused by $R$. stolonifer, all postharvest rots of dragon fruit have their origin either as latent infections in the field or as surface-borne spores. Many of the rot pathogens could grow at low temperatures and surface-borne Fusarium and Alternaria species were able to infect the fruit during storage. To test the effect of hot water treatments (HWTs) on postharvest rots, freshly harvested fruit were immersed at 49 , 51,53 , and $55^{\circ} \mathrm{C}$ for two or three minutes, stored at $5-6^{\circ} \mathrm{C}$ for 28 days and 3 days shelf life. HWTs at $49^{\circ} \mathrm{C}$ and $51{ }^{\circ} \mathrm{C}$ for two or three minutes both completely inhibited rots during storage, and after the shelf-life, significantly fewer rots were observed than other HWTs and the untreated control. The 49 and $51{ }^{\circ} \mathrm{C}$ HWTs also showed the least weight loss no damage to bracts, and no effect on titratable acidity, total soluble solids, fruit firmness, or flesh or skin colour. Current gaps in knowledge of postharvest rots and research strategies to address them are outlined in the paper.
\end{abstract}

\section{Introduction}

In recent years, dragon fruit [Hylocereus undatus (Haw.), Britton and Rose] has become one of Vietnam's major crops. However, dragon fruit are susceptible to a wide

\section{Article Info}

Accepted: 26 April 2017

Available Online: 06 May 2017

\section{Keywords}

Heat treatment

Infection

Pathogens

Pitaya

Postharvest

Storage 
associated with postharvest rots of dragon fruit outside of Vietnam including Alternaria sp., Ascochyta sp., Aspergillus sp., Bipolari ssp., Botryosphaeria dothidea, Capnodium sp., Colletotrichum gloeosporioides, Colletotrichum truncatum, Dothiorella sp., Fusarium semitectum, Fusarium sp., Gloeosporium agaves, Marssonina agaves, Phytophthora sp. and Sphaceloma sp. (Valencia-Botin et al., 2003; Wang and Lin, 2005; Le Bellec et al., 2006; Taba et al., 2007; Palmateer et al., 2007; Paull, 2007; Sijam et al., 2008; Masyahit et al., 2009a; Masyahit et al., 2009b; Masratul Hawa et al., 2010; Guo et al., 2013).

The pathogens reported to be most commonly associated with postharvest rots of dragon fruit in Vietnam are: Alternaria. spp., Bipolaris cactivora, Colletotrichum gloeosporioides, Curvularia lunata, F. oxysporium, Fusarium sp., Phomopsis sp., Rhizopus sp. (To et al., 2000; Ha, 2004; FAO, 2004; He et al., 2012). However, little information is available on the range of species consistently associated with postharvest rots in the Mekong Region, the origins of these infections, and appropriate postharvest rot control measures.

Use of postharvest fungicides is not an acceptable rot control strategy because of food safety risks and market access requirements. Heat treatment has been widely used as a viable alternative to control postharvest rots in a variety of fruit and vegetable crops (Fallik et al., 2001; Lana et al., 2005; Crowe et al., 2012; Shin et al., 2012). The mode of action of the hot water treatment relies on the ability of the treatment to kill or devitalize the pathogens without affecting the quality of the treated produce (Lurie et al., 1996). Hot water treatment of spores of Fusarium equiseti and $F$. dimerum, pathogens commonly causing post-harvest rots on white flesh dragon fruit, inhibited germination by $70-80 \%$ compared with untreated controls (Ngoc et al., 2015).

This paper aims to determine the most common postharvest pathogens in the Mekong Region, define the sources of infection, determine the heat tolerance of the pathogens, and examine the use of HWTs to minimize or eliminate postharvest rots.

\section{Materials and methods}

The experiments were carried out in the Division of Postharvest Technology, Southern Horticulture Research Institute (SOFRI) Viet Nam, over the period August 2013 to April 2016.

\section{Isolation and identification of postharvest pathogens}

White fleshed dragon fruit ('Thanh Long') was harvested from orchards in two provinces in the Mekong Delta Region, Long An and Tien Giang, Fruit were washed, dried, placed individually in perforated plastic bags and placed in boxes (10 fruits per box). Two boxes of fruit from each province were placed in controlled temperature cabinets set at 0,5 and $10^{\circ} \mathrm{C}$ for 21 and 26 days and held at $20^{\circ} \mathrm{C}$ for three days to simulate a shelf life period. Four boxes of 10 fruits from each orchard were held at $20^{\circ} \mathrm{C}$ for 7 and 12 days to serve as non-stored controls. After the designated storage periods fruit quality was assessed (Woolf et al., 2006).

Fruit rots appearing on fruit were examined and categorized according to symptom characters. The different types of symptoms were described and photographed. To isolate the causal organisms into pure culture, tissue taken aseptically from beneath the epidermis at the lesion margin and grown on Potato Dextrose Agar (PDA) containing of penicillin and streptomycin to inhibit bacterial growth.

Two methods were used to verify the pathogenicity of the isolates: 1. Small portions of pure culture were inserted into small $\mathrm{V}$ cuts in the skin of healthy dragon fruit, and the cut sealed with adhesive tape. 2. A drop of dilute suspension of spores of each species was placed on the skin of the fruit and allowed to dry down to adhere the spores to the epidermis. The fruit was then misted with water and the fruit incubated in humid chambers. The inoculated fruits were incubated at both room temperature (approximately $30^{\circ} \mathrm{C}$ ) and at $5-6^{\circ} \mathrm{C}$, the normal storage temperature for dragon fruit, until lesions were formed. Re-isolations were made from the lesions to complete Koch's postulates.

The cultures were identified on the basis of colony morphology, fruiting structures, and spores (if present). To confirm the species identities, colonies were sent to a private biotechnology company(Nam Khoa Biotek, Ho Chi Minh City) for sequencing of the internally transcribed spacer (ITS) region of ribosomal DNA and the comparing with sequences previously lodged in GenBank. Representative samples of each species are stored at SOFRI in sterile water at $5^{\circ} \mathrm{C}$ for use as reference cultures for future identification and research. 


\section{Origins of infections by postharvest pathogens (rainy season)}

Endophytic infections: Ten fruit healthy fruit were harvested from the field, washed in water, surface sterilized in a chlorine solution (200ppp) for 3 minutes then wiped with $95 \%$ ethanol. Twenty pieces of skin 0.5 $\mathrm{x} 0.5 \mathrm{~cm}$ were removed from each fruit, placed on sterile absorbent paper in Petri dishes and left overnight to freeze at $0^{\circ} \mathrm{C}$ to kill the skin tissue. The skin pieces were then transferred to PDA and incubated. Fungi growing out from the skin pieces were isolated into pure culture and identified.

Surface spores: The skins of 10 healthy fruit were swabbed in the field seven days before harvest using sterile medical swabs dipped in sterile water. The swabs were then streaked over the surface of PDA in Petri dishes. Fungi growing on the PDA were isolated into pure culture and identified. The process was repeated on 10 ripe fruit after harvest.

\section{Growth response of pathogens in vitro to temperature}

Small pieces from 10 day old cultures of the most commonly occurring pathogens were placed on Petri plates of PDA and incubated at a range of temperatures $\left(5,10,15,20,25,30,35,40\right.$ and $\left.45^{\circ} \mathrm{C}\right)$. The colony margin was marked on two opposing sides at the same time daily, and growth rate calculated as the increase in colony diameter in $\mathrm{mm} / 24 \mathrm{hrs}$ averaged over a period of 5-8 days.

\section{Effects of hot water treatment on rot incidence and fruit quality}

The experiment was carried out in February, 2016 (dry season). It used a randomized complete block design with 2 factors, treatment time and water temperature, each with three replicate boxes of 8 fruit.

Fruits were immersed in hot water at $49,51,53,55^{\circ} \mathrm{C}$ and a control of ambient water $\left(30^{\circ} \mathrm{C}\right)$ for two and or three minutes. The treated fruit were stored at $5-6^{\circ} \mathrm{C}$ for 28 days then at $20^{\circ} \mathrm{C}$ for a three days shelf life. After the designated storage periods the fruit were examined and assessed for incidence and severity of disease, weight loss and the quality parameters bract condition, soluble solids concentration (SSC), titratable acidity (TA), flesh and skin colour, and heat damage.
Rot severity and heat damage (browning and fine cracking of epidermis) were assessed according to the percentage of surface area covered using the grading scale of Woolf et al. (2006) where: $0=$ no rots; $0.5=$ $<5 \% ; 1=5-10 \% ; 1.5=10-15 \% ; 2=15-25 \% ; 2.5=>25$ $50 \%) ; 3=>50 \%$.

Bract condition was assessed according the 0-5 scale of Woolf et al. (2006) where: $0=$ bright green, red colour, no browning/blackening, firm, no shrivel and $5=$ black, dry, and completely shrivelled. SSC (\%) was determined on this liquid using a refractometer. TA is expressed as the amount of free acid in the product (\% or $\mathrm{g} / 100 \mathrm{~mL}$ ). Fruit firmness $\left(\mathrm{kg} . \mathrm{cm}^{-2}\right)$, was measured using Penetrometer (model FT 327, place of manufacture), measure using an $11 \mathrm{~mm}$ diameter conical head. Skin colour was measured with a Minolta chromameter CR 300 (place of manufacture) using a D65 filter.

\section{Data analysis}

Percentage data were arcsin transformed prior to analysis. Data were analysed by Analysis of Variance (ANOVA) to detect significant treatment effects and comparisons of treatment means were performed using the Least Significant Difference (LSD) at $1 \%$ level of significance with SAS software, version 8.1.

\section{Results}

\section{Postharvest pathogens most often detected}

The species of fungi most frequently isolated, of confirmed pathogenicity, and identified on the basis of morphology and ITS sequencing were Alternaria alternata, Bipolaris cactivora, Colletotrichum truncatum, Fusarium dimerum, Fusarium equiseti and Rhizopus stolonifer. Images of symptoms, colony characteristics and reproductive structures were assembled in a plate as an aid to future identification of rots of stored fruit (Fig. 1).

Infections by the different pathogens yield characteristically different symptoms. Typical symptoms of the different pathogens are:

A. alternata - lesion sunken, margin yellow, gray mycelium on surface, rapid spread;

B. cactivora - lesion large irregular in outline, wide, light brown margin, dense black fungal growth 
in centre of lesion;

C. truncatum- lesion flat circular or irregular, light brown margin, black fruiting bodies in centre of lesion;

F. dimerum - lesion sunken, soft, dark brown, rapid spread;

F. equiseti - lesion sunken, soft, ivory-white with diffuse margin, rapid spread;

$R$. stolonifer - rapidly spreading water-soaked soft rot, extensive leakage of cellular contents, later forming extensive grey mycelium with profuse black sporangial heads on surface.

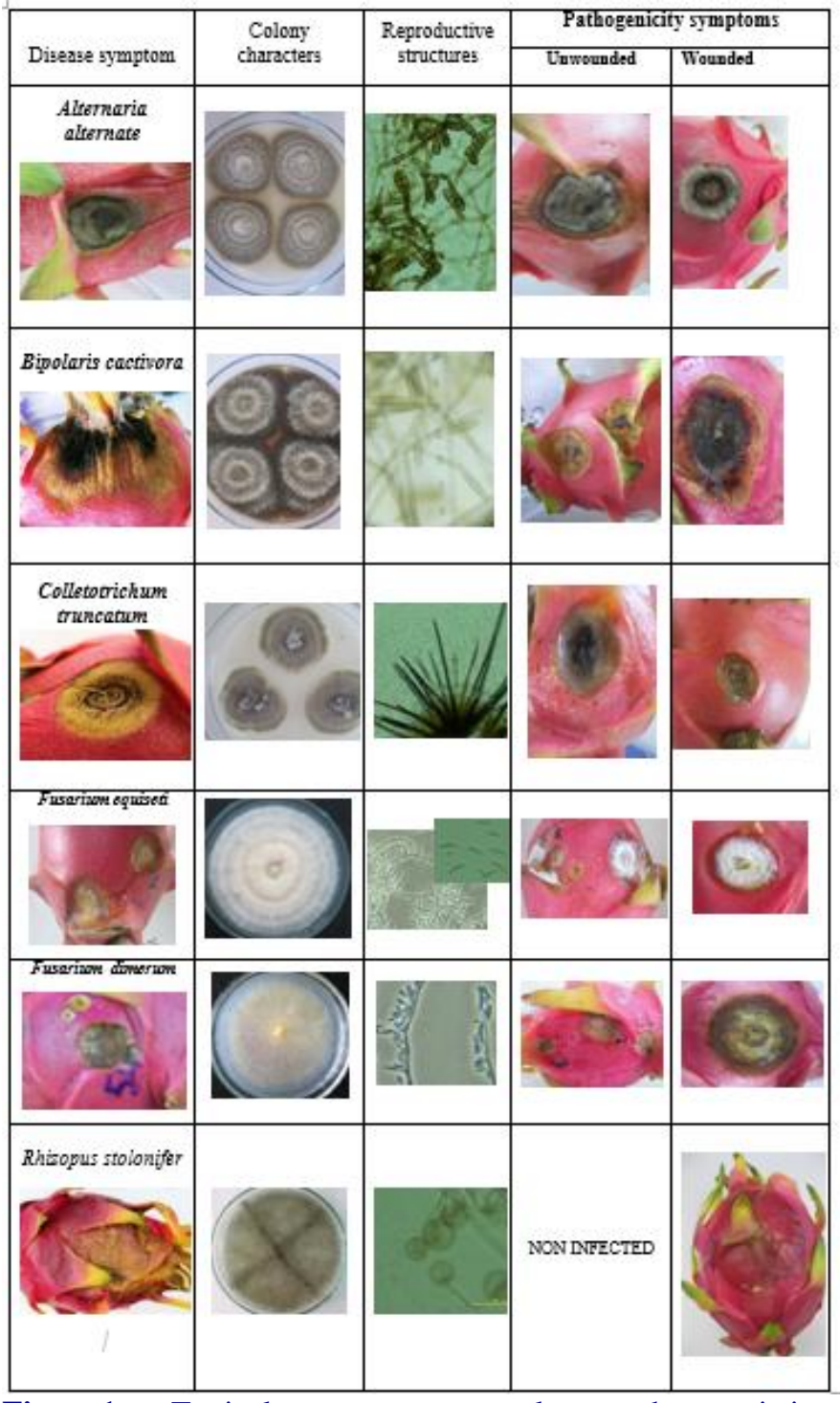

Fig. 1: Typical symptoms, colony characteristics, reproductive structures and disease expression after inoculation of main fungi associated with rots on white flesh dragon fruit.
The results of the pathogenicity test are shown in Table 1 . At $30^{\circ} \mathrm{C}$, all of the pathogens inoculated by wounding progressed to form rots, and all except $R$. stolonifer infected the fruit without wounding. When fruit were inoculated by wounding and stored $5-6^{\circ} \mathrm{C}$ only $A$. alternata, $F$. dimerum and $F$. Equiseti progressed to form rots, but the remainder survived and formed rots during the post-storage period. When surface-inoculated (no wounding) none of the pathogens infected and caused rots during storage, but all except $R$. stolonifer infected during the $20^{\circ} \mathrm{C}$ post-storage period.

\section{Origins of infection by postharvest pathogens}

Skin pieces isolated from fruit collected in the field and surface sterilised to remove surface microorganisms yielded $C$. truncatum, $F$. dimerum, $F$. equiseti, $A$. alternate and B. cactivora. All of these pathogens were present as latent infections in the skin of fruit in the field.

Surface swabs taken from fruit in the field either seven days before harvest or at harvest, yielded Alternaria sp. and Fusarium sp.

\section{Temperature tolerance of pathogens}

The relative growth rates of -each of the pathogens at different temperatures are shown in Fig. 2. The results show that many of the rot pathogens were able to grow at relatively low temperatures, however only $A$. alternata was able to growth at $5^{\circ} \mathrm{C}$. F. dimerum, $F$. equiseti and B. cactivora were able to make some growth at $10^{\circ} \mathrm{C}$. All except $B$. cactivora and $R$. stolonifer had their maximum growth rate in the range $25-30^{\circ} \mathrm{C}$. B. cactivora and $R$. stolonifer had maximum growth at $35^{\circ} \mathrm{C}$, and later declined with further increase in temperature. None of the fungi were able to grow at $40^{\circ} \mathrm{C}$. $R$. stolonifer had an extremely rapid growth rate increasing from $60 \mathrm{~mm} / 24 \mathrm{hrs}$ at $15^{\circ} \mathrm{C}$ to $90 \mathrm{~mm} / 24 \mathrm{hrs}$ at $35^{\circ} \mathrm{C}$.

\section{Effects of hot water treatment on rots and fruit quality}

The results after hot water treatment, cool storage and subsequent incubation at $30^{\circ} \mathrm{C}$ are shown in Table 2 . Fruit treated at $49^{\circ} \mathrm{C}$ and $51^{\circ} \mathrm{C}$ for 2 and for 3 minutes were essentially free from rots when removed from the cool store. All other treatments were less effective but disease incidence and severity were significantly lower than on control fruit. There was rot expression on all 
fruit during the subsequent storage period at $30^{\circ} \mathrm{C}$ but both disease incidence and severity were lowest in treatments in the temperature range $49-53^{\circ} \mathrm{C}$ for two or three minutes. However there was significant heat injury to the fruit for both treatment times at treatment temperatures above $51^{\circ} \mathrm{C}$.

Table 1. Infection of dragon fruit by different pathogens using different inoculation methods and incubation conditions.

\begin{tabular}{|c|c|c|c|c|c|c|}
\hline \multirow[t]{2}{*}{ Treatment } & \multicolumn{3}{|c|}{ Inoculation with wound } & \multicolumn{3}{|c|}{ Inoculation without wound } \\
\hline & $\begin{array}{l}28 \text { days at } \\
5^{\circ} \mathrm{C}\end{array}$ & $\begin{array}{l}28 \text { days at } 5^{\circ} \mathrm{C} \\
+5 \text { days at } 20^{\circ} \mathrm{C}\end{array}$ & $\begin{array}{l}5 \text { days at } \\
30^{\circ} \mathrm{C}\end{array}$ & $\begin{array}{l}28 \text { days } \\
\text { at } 5^{\circ} \mathrm{C}\end{array}$ & $\begin{array}{l}28 \text { days at } 5^{\circ} \mathrm{C} \\
+5 \text { days at } 20^{\circ} \mathrm{C}\end{array}$ & $\begin{array}{l}5 \text { days at } \\
30^{\circ} \mathrm{C}\end{array}$ \\
\hline Alternaria alternata & + & + & + & + & + & + \\
\hline Colletotrichum truncatum & - & + & + & - & + & + \\
\hline Fusarium equiseti & + & + & + & - & + & + \\
\hline
\end{tabular}

- no symptoms formed; + symptoms formed

Table 2. Effect of hot water in management of postharvest rot and heat damage on dragon fruit. Percentage data were converted to arcsin values for analysis. Non-transformed data are shown in the table.

\begin{tabular}{|c|c|c|c|c|c|c|}
\hline \multirow[t]{2}{*}{ Treatment } & \multicolumn{2}{|c|}{28 days at $5^{\circ} \mathrm{C}$} & \multicolumn{2}{|c|}{$\begin{array}{l}28 \text { days at } 5^{\circ} \mathrm{C} \\
+3 \text { days at } 20^{\circ} \mathrm{C}\end{array}$} & \multicolumn{2}{|c|}{$\begin{array}{l}\text { Heat damage } \\
\left(28 \text { days at } 5^{\circ} \mathrm{C}\right)\end{array}$} \\
\hline & PDI (\%) & PDS (\%) & PDI (\%) & PDS (\%) & PHI (\%) & PHS (\%) \\
\hline Dip $49 / 2$ mins & $0.00 \mathrm{~b}$ & $0.00 \mathrm{c}$ & $8.33 \mathrm{ef}$ & $7.50 \mathrm{~cd}$ & $0.00 \mathrm{c}$ & $0.00 \mathrm{c}$ \\
\hline Dip $51 / 2$ mins & $0.00 \mathrm{~b}$ & $0.00 \mathrm{c}$ & $2.08 \mathrm{f}$ & $6.67 \mathrm{~d}$ & $0.00 \mathrm{c}$ & $0.00 \mathrm{c}$ \\
\hline Dip 51/3mins & $0.00 \mathrm{~b}$ & $0.00 \mathrm{c}$ & $16.67 \mathrm{cdef}$ & 20.00abcd & $0.00 \mathrm{c}$ & $0.00 \mathrm{c}$ \\
\hline Dip $55 / 2$ mins & $0.00 \mathrm{~b}$ & $0.00 \mathrm{c}$ & $75.00 \mathrm{ab}$ & $46.81 \mathrm{ab}$ & $100.00 \mathrm{a}$ & $60.00 \mathrm{c}$ \\
\hline Dip $55 / 3$ mins & $12.50 \mathrm{a}$ & $4.17 \mathrm{a}$ & $87.50 \mathrm{a}$ & $49.96 \mathrm{a}$ & $100.00 \mathrm{a}$ & $68.75 \mathrm{c}$ \\
\hline Control $/ 2 \mathrm{mins}$ & $12.50 \mathrm{a}$ & $2.50 \mathrm{ab}$ & $37.50 \mathrm{~cd}$ & $26.11 \mathrm{abcd}$ & $0.00 \mathrm{c}$ & $0.00 \mathrm{c}$ \\
\hline Control $/ 3 \mathrm{mins}$ & $8.33 \mathrm{ab}$ & $0.83 b c$ & $33.33 \mathrm{~cd}$ & $36.67 \mathrm{abc}$ & $0.00 \mathrm{c}$ & $0.00 \mathrm{c}$ \\
\hline $\mathrm{CV}(\%)$ & 70.07 & 53.00 & 28.74 & 39.17 & 24.01 & 26.58 \\
\hline LSD (1\%) temp. & 10.23 & 3.80 & 15.32 & 16.98 & 9.17 & 18.31 \\
\hline
\end{tabular}

Note: PDI: percent disease incidence; PDS: percent disease severity; PHI: percent heat damage incidence; PHS: percent heat damage severity.

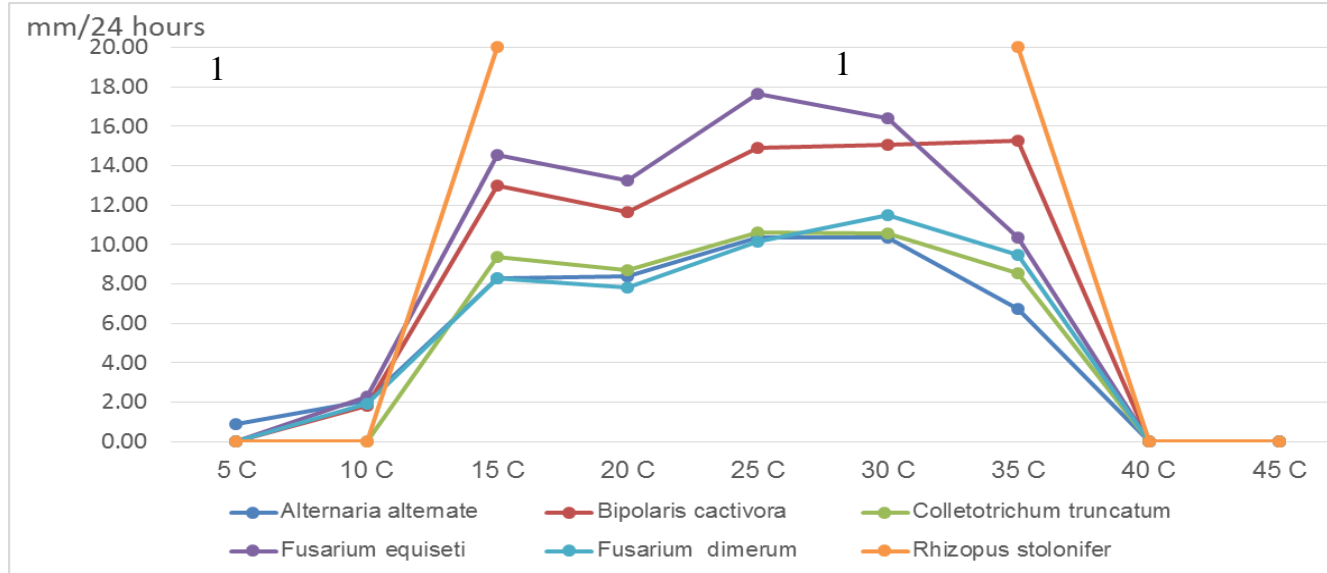

${ }^{1}$ Rhizopus stolonifer growth rate increased from $60 \mathrm{~mm} / 24 \mathrm{hr}$ at $15^{\circ} \mathrm{C}$ to $90 \mathrm{~mm} / 24 \mathrm{hr}$ at $35^{\circ} \mathrm{C}$

Fig. 2: Growth rates of postharvest pathogens at a range of different temperatures on PDA plates. 
The effect of the treatments on SSC, TA and bract appearance is shown in Table 3. Hot water treatments above $51^{\circ} \mathrm{C}\left(53\right.$ and $\left.55^{\circ} \mathrm{C}\right)$ significantly increased weight loss and bract damage, and reduced fruit firmness. None of the temperature time combinations significantly affected SSC or TA. None of the temperature time combinations had a significant effect on either fruit flesh or skin colour (data not shown).

Table 3. Effect of hot water treatments of dragon fruit on total total soluble solids, titratable acidity, fruit firmness and bract appearance.

\begin{tabular}{|c|c|c|c|c|c|}
\hline \multirow[b]{2}{*}{ Treatment } & \multicolumn{2}{|l|}{28 days at $5^{\circ} \mathrm{C}$} & \multicolumn{3}{|c|}{28 days at $5^{\circ} \mathrm{C}+3$ days at $20^{\circ} \mathrm{C}$} \\
\hline & Weight loss (\%) & $\begin{array}{l}\text { Bract } \\
\text { appearance }^{1}\end{array}$ & TA $(\%)$ & $\operatorname{SSC}(\%)$ & 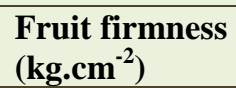 \\
\hline Dip $49 / 2$ mins & 3.34 bcd & $1 \mathrm{~d}$ & $0.09 \mathrm{a}$ & $10.02 \mathrm{ab}$ & $0.74 \mathrm{~b}$ \\
\hline Dip 49 /3mins & $3.02 \mathrm{~cd}$ & $1 \mathrm{~d}$ & $0.10 \mathrm{a}$ & $10.35 \mathrm{a}$ & $0.82 \mathrm{ab}$ \\
\hline Dip $51 / 2$ mins & $2.41 \mathrm{~d}$ & $1 \mathrm{~d}$ & $0.10 \mathrm{a}$ & $9.45 \mathrm{ab}$ & $0.84 \mathrm{ab}$ \\
\hline Dip 51/3mins & $4.25 \mathrm{ab}$ & $3 \mathrm{~b}$ & $0.10 \mathrm{a}$ & $9.98 \mathrm{ab}$ & $0.83 \mathrm{ab}$ \\
\hline Dip $53 / 2$ mins & $4.23 \mathrm{ab}$ & $3 \mathrm{~b}$ & $0.12 \mathrm{a}$ & $10.45 \mathrm{a}$ & $0.78 \mathrm{ab}$ \\
\hline Dip $53 / 3$ mins & $4.53 \mathrm{a}$ & $3 \mathrm{~b}$ & $0.09 \mathrm{a}$ & $9.80 \mathrm{ab}$ & $0.87 \mathrm{ab}$ \\
\hline Dip $55 / 2$ mins & $4.67 \mathrm{a}$ & $4 \mathrm{a}$ & $0.11 \mathrm{a}$ & $8.98 \mathrm{~b}$ & $0.78 \mathrm{ab}$ \\
\hline Dip $55 / 3$ mins & $3.74 \mathrm{abc}$ & $4 \mathrm{a}$ & $0.10 \mathrm{a}$ & $9.25 \mathrm{ab}$ & $0.82 \mathrm{ab}$ \\
\hline Control $/ 2 \mathrm{mins}$ & $2.58 \mathrm{~d}$ & $2 \mathrm{c}$ & $0.11 \mathrm{a}$ & $9.97 \mathrm{ab}$ & $0.79 \mathrm{ab}$ \\
\hline Control $/ 3$ mins & $2.46 \mathrm{~d}$ & $1.5 \mathrm{dc}$ & $0.10 \mathrm{a}$ & $9.98 \mathrm{ab}$ & $0.88 \mathrm{a}$ \\
\hline $\mathrm{CV}(\%)$ & 9.63 & 9.52 & 18.25 & 3.64 & 4.71 \\
\hline LSD (1\%) temp. & 0.76 & 0.50 & 0.04 & 0.80 & 0.09 \\
\hline Significance & $* *$ & $* *$ & $\mathrm{~ns}$ & $* *$ & $\mathrm{~ns}$ \\
\hline LSD (1\%) time & 0.48 & 0.32 & 0.03 & 0.51 & 0.05 \\
\hline Significance & $\mathrm{ns}$ & $\mathrm{ns}$ & ns & ns & $* *$ \\
\hline
\end{tabular}

\section{Discussion}

This study has shown that A. alternata, B. cactivora, $C$. truncatum, $F$. dimerum, $F$. equiseti and $R$. stolonifer are the most common postharvest pathogens affecting dragon fruit in the Mekong Delta region. The species identified here fall within the range of species reported by To (2000), Ha (2004) and He et al. (2012).

While the rots caused by these species express only during or immediately after storage, isolations from the skin of fruit fresh from the field has confirmed that all of those species have the ability to infect fruit in the field and can be carried into storage as latent infections in the skin of apparently healthy fruit. In addition, all species except $R$. stolonifer have the ability to infect directly from spores on the skin after harvest and to cause rots. Because of their ability to grow at low temperatures, several species which can be carried from the field as latent infections ( $F$. quiseti, $F$. dimerum and A. alternata) have the ability to initiate rots during the storage period.

Therefore treatments aimed at reducing postharvest rots should consider control in the field, disinfection of spores on the skin surface, and killing or devitalising those already within the skin at harvest. This study has shown that the immersion of dragon fruit in water at temperatures in the range of $49-51^{\circ} \mathrm{C}$ for two or three minutes is effective at minimising postharvest rots without causing physiological damage to the fruit in terms of weight loss, SSC, TA, and fruit firmness, and does not affect either flesh or skin colour.

The knowledge that all of the postharvest pathogens can be carried into storage as latent infections in the fruit offers an alternative strategy for reducing rots. Fungicides are routinely used for the control of canker and other fungal diseases in the orchard. The targeted application of selected fungicides to developing fruit, or covering the fruit to exclude spores may offer an additional strategy for the control of postharvest rots.

Future studies planned to minimize postharvest rots and extend the storage period (currently only 5 to 6 weeks) including pre-harvest field hygiene and fungicide strategies and postharvest treatments including sanitizers, heat treatment and modified atmosphere packaging. 


\section{Conflict of interest statement}

Authors declare that they have no conflict of interest.

\section{Acknowledgement}

We acknowledge the support of the New Zealand Ministry of Foreign Affairs, The New Zealand Institute for Plant and Food Research Limited and the Southern Fruit Research Institute for providing the financial and technical support to carry out the present investigations. We also would like to thank our colleagues in the Postharvest Technology Division as for technical assistance during the project.

\section{References}

Crowe, K.M., Bushway, A., Davis-Dentici, K., 2012. Impact of postharvest treatments, chlorine and ozone, coupled with low-temperature frozen storage on the antimicrobial quality of low bush blueberries. LWT - Food Sci. Technol. 47, 213-215.

Fallik, E.,Tuvia-Alkalai, S., Feng, X., Lurie, S., 2001. Ripening characterisation and decay development of stored apples after a short pre-storage hot water rinsing and brushing. Innov. Food Sci. Emerg. Technol. 2, 127-132.

FAO, 2004. Fruit of Vietnam. Regional Office for Asia and the Pacific. Food and Agriculture Organization, Bangkok, Thailand.

Guo, L. W., Wu, Y.X., Ho, H.H., Su, Y.Y., Mao, Z. C., He, P.F., He, Y.Q., 2013. First report of dragon fruit (Hylocereus undatus) anthracnose caused by Colletotrichum truncatum in China. J. Phytopathol. 4, 209-276.

Ha, T. V., 2004. Diseases of dragon fruit tree and the effects of heat treatment with steam to pathogens and fruit quality after harvest. Master's Thesis Agricultural Sector of Plant Protection, University of Agriculture and Forestry, Ho Chi Minh City.

He, P.F., Ho, H., Wu, X.X., Hou, M.S., He, Y.Q., 2012. Bipolaris cactivora causing fruit rot of dragon fruit imported from Vietnam. Plant Pathol. Quar. DOI $10.5943 / \mathrm{ppq} / 2 / 1 / 5$.

Lana, M. M., Tijskens, L. M. M., Kooten, O. Van., 2005. Effect of storage temperature and fruit ripening on firmness of fresh-cut tomatoes. Postharv. Biol. Technol. 35, 87-95.

Le Bellec, F., Vaillant, F., Imbert, E., 2006. Pitahaya (Hylocereus spp.): A new fruit crop, a market with a future. Fruits. 61, 237-250.
Lurie, S., Fallik, E., Klein, J. D., 1996. The effect of heat treatment on apple epicuticular wax and calcium uptake. Postharv. Biol. Technol. 8, 271-277.

Masratul Hawa, M., Salleh, B., Latiffah, Z., 2010. Characterization and intraspecific variation of Fusarium semitectum (Berkeley and Ravenel) associated with red-fleshed dragon fruit (Hylocereus polyrhizus [Weber] Britton and Rose) in Malaysia. Afr. J. Biotechnol. 9(3), 273-284.

Masyahit, M., Sijam, K., Awang,Y., Satar, M.G.M., 2009a. The first report of the occurrence of anthracnose disease caused by Colletotrichum gloeosporioides (Penz.) Penz. \& Sacc. on dragon fruit (Hylocereus spp.) in Peninsular Malaysia. Am. J. Appl. Sci. 6(5), 902-912.

Masyahit, M., Sijam, K., Awang, Y., Satar, M.G.M., 2009b. In vitro assay of factors affecting the growth of pathogens associated with diseases on dragon fruit (Hylocereus spp.) in Peninsular Malaysia. Plant Pathol. J. 8(4), 144-151.

Ngoc, N. K., van Phong, G., Fullerton, B., 2015. Study of post-harvest diseases on dragon fruit (Hylocereus undatus Haw.) causing by species of Fusarium spp. and the treating of hot water and sanitizer (Chlorine). Vietnam. J. Plant Prot. No. 4, p.42.

Palmateer, A.J., Ploetz, R.C., Van Santen, E., Correll, J.C., 2007. First report of anthracnose caused by Colletotrichum gloeosporioides on Pitaya. Plant Dis. 91, 631-631.

Paull, R.E., 2007. Dragon Fruit. Department of Tropical Plant and Soil Sciences University of Hawaii, Manoa, Honolulu.

Shin, Y. J., Song, H. Y., Song, K., 2012. Effect of a combined treatment of rice bran protein film packaging with aqueous chlorine dioxide washing and ultraviolet-C irradiation on the postharvest quality of 'Goha' strawberries. J. Food Eng. 113, 374-379.

Sijam, K., Awang, Y., Satar, M.G.M., 2008. Fungi associated with diseases on dragon fruit (Hylocereus spp.) in Peninsular Malaysia. Proceedings of the Microbes: Biotechnology Engine for Health and Wealth Creation. Hyatt Regency Resort, Kuantan, Pahang Darul Makmur, Malaysia, Aug. 16-19, Malaysian Society for Microbiology. pp.234-237.

Taba, S., Miyahira, N., Nasu, K., Takushi, T., Moromizato, Z., 2007. Fruit rot of strawberry pear (pitaya) caused by Bipolaris cactivora. J. General Plant Pathol. 73(5), 374-376.

To, L.V., Ngu, N., Duc, N. D., Trinh, D.T.K., Thanh, N.C., Mien, D.V.H., Chau, H. N., Long, T.N., 2000. 
Quality assurance system for dragon fruit. Quality Assurance in Agricultural Produce, ACIAR Proc. No. 100. pp.101-114.

Valencia-Botín, A. J., Sandoval-Islas, J. S., CárdenasSoriano, E., Michailides, T. J., Rendón-Sánchez, G., 2003. Botryosphaeria dothidea causing stem spots on Hylocereus undatus in Mexico. Plant Pathol. 52,
803-803.

Wang, C.L., Lin, C.C., 2005. Fruit rot of pitaya dan stem rot of cacti in Taiwan. Plant Pathol. Bull., 14: 269274.

Woolf, A.B., Hien, D.M., Hoa, T.T., Jackman, R., Clark, C., 2006. Hort Research \& SOFRI Dragon Fruit Assessment Manual, ISBN: 0-478-06839-5. 23p.

\section{How to cite this article:}

Ngoc, N. K., van Phong, N., Tung, N.T., van Hoa, N., Woolf, A.B., Fullerton, R.A., 2017. Postharvest diseases and effect of hot water treatments on white fleshed dragon fruit [Hylocereus undatus (Haw.) Britton \& Rose]. Int. J. Curr. Res. Biosci. Plant Biol. 4(5), 30-37. doi: https://doi.org/10.20546/ijcrbp.2017.405.003 